\title{
Pengembangan Modul Pembelajaran Bahasa Inggris Berbasis HOTS untuk Kelas VII
}

\author{
Harisna Hikmah, Edy Wahyu Wibowo \\ Universitas Nahdlatul Ulama Yogyakarta \\ ryshnano@unu-jogja.ac.id
}

\section{Sejarah Artikel}

diterima 28 Oktober 2020 disetujui 20 November 2020 diterbitkan 1 Desember 2020

\begin{abstract}
This study is aimed to develop English learning module for grade seventh students of MTs Al Falaah Pandak which is based on Higher Order Thinking Skills. This study implemented quantitative and qualitative research methods. The quantitative data is gained from the questionnaire given to the expert and students. Meanwhile, the qualitative data is gained from the observation, book analysis, and comments from the expert validator. The result of this study is a product of learning module contains materials and learning activities based on the familiarization of higher order thinking skills. It includes the ability to analyze, evaluate, create or produce. The mean score gained from the expert judgment is 3,48 and the mean score from the students' questionnaire is 3,23 which means that this module is good or proper to be used.

Keywords: learning module, English, HOTS
\end{abstract}

\begin{abstract}
Abstrak
Penelitian ini bertujuan untuk mengembangkan modul pembelajaran Bahasa Inggris berbasis HOTS bagi siswa kelas VII MTs. Penelitian ini menerapkan metode penelitian kualitatif dan kuantitif. Data kuantitatif diperoleh dengan menggunakan angket dan data kualitatif diperoleh dengan menggunakan Teknik observasi, analisis buku, dan komentar dari validator ahli. Hasil dari penelitian ini adalah terciptanya modul pembelajaran Bahasa Inggris untuk kelas VII MTs Al Falaah Pandak yang berisi tentang materi dan aktifitas - aktifitas pembelajaran yang berbasis pada pembiasaan kemampuan berfikir tingkat tinggi (HOTS) yang mencakup pada menganalisis, mengevaluasi, dan mencipta atau memproduksi. Hasil dari nilai rerata validitas ahli sebesar 3.48 dan hasil angket siswa sebesar 3,23 yang menyatakan bahawa modul ini layak digunakan.
\end{abstract}

Kata kunci: modul pembelajaran, Bahasa Inggris, HOTS

e-ISSN 2581-1835

p-ISSN 2581-1843

This work is licensed under a Creative Commons Attribution-ShareAlike 4.0 International License. 


\section{PENDAHULUAN}

Pembelajaran Bahasa Inggris di era revolusi industry ini memegang peranan penting. Karena Bahasa Inggris merupakan Bahasa internasional yang menjadi Bahasa penghubung antar negara. Oleh karena itu pemerintah Indonesia menetapkan Bahasa Inggris sebagai mata pelajaran wajib di tingkat sekolah menengah (Margana, 2019). Tujuan pembelajaran Bahasa Inggris di level sekolah menengah adalah mengembangkan kompetensi berkomunikasi baik secara lisan mauoun tertulis. Untuk mencapai hal tersebut perlu disiapkan materi atau bahan ajar yang mampu memfasilitasi siswa dan guru dalam mencapai tujuan pembelajaran. Karena dalam pembelajaran Bahasa Inggris, ketersediaan bahan ajar merupakan salah satu factor penentu keberhasilan. Namun pada kenyataannya, guru disekolah cenderung mengandalkan buku dari penerbit dan dari pemerintah saja. Sehinga kelayakan isi dan desain buku materi tersebut belum bisa mencakup segala kebutuhan siswa akan materi tersebut atau kurang sesauai dengan karakter dari satuan Pendidikan tersebut.

Terlebih, dengan penerapan kurikulum 2013 di semua jenjang pendidikan di Indonesia, maka perubahan orientasi pengajaran pun berubah dan hal ini juga mengubah isi materi dari buku-buku yang sudah ada. Kurikulum 2013 ini berorientasi pada 3 aspek, yaitu aspek kogntif, afektif dan psikomotor. Hal ini sesuai dengan tujuan kurikulum 2013 yaitu 'mempersiapkan manusia yang beriman, produktif, kreatif, inovatif, dan afektif serta mampu berkontribusi pada kehidupan bermasyarakat, berbangsa, bernegara, dan peradaban dunia.' Tujuan ini tercantum didalam permendiknas No 70 Tahun 2013. Kurikulum 2013 ini berorientasikan pada Hingher Order Thinking Skill (HOTS) yang mencakup ketrampilan menganalisa (analyzing), menyusun (synthesizing), mengevaluasi (evaluating), mengaplikasikan (applying), dan mencipta (creating). Berbagai administrasi pembelajaran mulai dari silabus, rpp dan bahan ajar juga mengalami perubahan. Maka guru dituntut untuk mampu mengembangkan bahan ajar yang sesuai dengan kebutuhan dan karakter siswanya. Renandya (2013:11) menyatakan bahwa bahan ajar dikatakan baik apabila memenuhi apa yang dibutuhkan oleh siswa yang akan mempelajarinya. Terlebih, bahan ajar seharusnya bisa memotivasi para siswa untuk menguasai Bahasa target dengan efektif dan efisien. Terkait dengan HOTs, Bloom dalam Anderson dan Krathwohl (2001) menyatakan bahwa HOTs memiliki 4 aspek utama, yaitu mengaplikasikan, menganalisa, mengevaluasi, dan mencipta. Bahan ajar yang baik harus memenuhi beberapa kriteria. Kriteria bahan ajar yang baik menurut Hutchhinson dan Waters (1987:107) ada empat, yaitu: (1) bahan ajar harus memberikan dorongan kepada siswa untuk mampu belajar mandiri, (2) bahan ajar harus mampu memfasilitasi terjadinya proses pembelajaran struktur organiasasi penyajian materi yang saling terkait, (3) bahan ajar harus menghadirkan Bahasa target yang bisa dipahami oleh siswa, dan (4) bahan ajar tersebut harus focus pada kegiatankegiatan yang menantang siswa untuk berfikir. Jika dikaitkan dengan HOTs, 
maka bahan ajar ini harusnya mampu membuat siswa berfikir dengan kritis.

Dengan adanya tuntutan Kurikulum 2013 yang menyatakan siswa harus terbiasa sampai pada taraf mencipta, maka siswa harus terus menerus dilatih untuk menghasilkan sesuatu yang baru. Higher Order of Thinking Skill (HOTS) atau kemampuan berpikir tingkat tinggi merupakan suatu kemampuan berpikir yang tidak hanya membutuhkan kemampuan mengingat saja, namun membutuhkan kemampuan lain yang lebih tinggi, seperti kemampuan berpikir kreatif dan kritis. Maka modul bahasa Inggris yang berbasis pada HOTS harus mampu membuat siswa mempunyai kemandirian belajar dan mengembangkan kreatifitasnya sesuai dengan potensi yang pada akhirnya membuat siswa mampu menguasai bahasa Inggris pada tingkat functional, dimana pada tingkat functional, orang mampu menggunakan bahasa untuk memenuhi kebutuhan hidup seharihari seperti membaca surat kabar, manual atau petunjuk (Wells, 1987). Hal ini sejalan dengan penelitian yang dilakukan oleh Zahroh (2019) yang menyatakan bahwa HOTS sangat penting dalam meningkatkan kemampuan Bahasa Inggris yang produktif. Maka pengajaran dengan berbasis HOTS sangat direkomendasikan dalam meningkatkan kemampuan berbicara dan menulis. Maka pengembangan modul yang mencakup empat kemampuan dalam Bahasa masih sangat diperlukan.

$$
\text { MTs Al Falaah Pandak }
$$
merupakan madrasah setara dengan Sekolah Menengah Pertama yang berada dibawah naungan Kementerian Agama dan dibawah yayasan Lembaga Pendidikan Ma'arif
Kabupaten Bantul. Namun, dalam perkembangannya, pengelolaan di madrasah ini berada dibawah Pondok Pesantren Al Imdad Bantul. Madrasah ini memiliki siswa 484 siswa dengan 95\% siswanya merupakan santri mukim PP Al Imdad. Untuk kelas VII berjumlah 164 siswa dan seluruhnya adalah santri mukim. Sehingga madrasah ini mempunyai karakter dan kekhasan. Madrasah ini menerapkan kurikulum nasional, kurikulum kemeterian agama, dan juga kurikulum pesantren sehingga beban belajar siswa menjadi sangat banyak dan padat. Kenyataan ini membuat pengajaran di madrsah ini menjadi full day school dan dilaksankan selama 6 hari per minggunya. Maka performa guru, metode pengajaran, kesiapan bahan ajar harus dibuat menarik agar siswa tetap semangat dalam belajar, khususnya belajar bahasa Inggris yang merupakan mata pelajaran wajib di madrasah ini.

Berdasarkan wawancara dan observasi penulis di madrasah tersebut, guru dan siswa hanya menggunakan satu buku pegangan dan 1 LKS untuk bahan mengajar dan jarang menggunakan sumber lain. Selain itu, guru juga belum mempuyai pengalaman atau pelatihan dalam penyusunan bahan ajar yang menerapkan kurikulum 2013 dan berorientasi pada HOTS. Oleh karena hal-hal yang tersebut diatas, maka penelitian ini mencoba untuk melalukan inovasi dengan mengembangkan modul modul yang berorientasikan HOTS dan sesuai dengan kurikulum 2013 untuk siswa kelas VII. Dalam modul ini dikembangkan pula media video pelengkap modul untuk membiasakan siswa mendengarkan dan menganalisis Bahasa yang muncul dalam video tersebut. Dengan 
pengembangan modul ini, tentunya diharapkan proses pembiasaan siswa untuk menganalisis, mengevaluasi dan mencipta dapat terwujud sehingga kemampuan Bahasa Inggris siswa dapat meningkat.

\section{METODE}

Penelitian ini menggunakan metode penelitian pengambangan (Research and Development) yang hasil akhirnya berupa produk. Model yang digunakan dalam penelitian ini adalah model yang dikembangkan oleh Thomlinson (1998). Lima prosedur penelitian pengembangan yang akan dijadikan pedoman dalam penelitian pengembangan ini adalah: (1) conducting need analsis, (2) stating goal and objectives, (3) desgning syllabus design, (4) developing methodology/materia, dan (5) conducting testing and evaluation. Adapun alur penelitian bisa dilihat dari diagram di bawah:

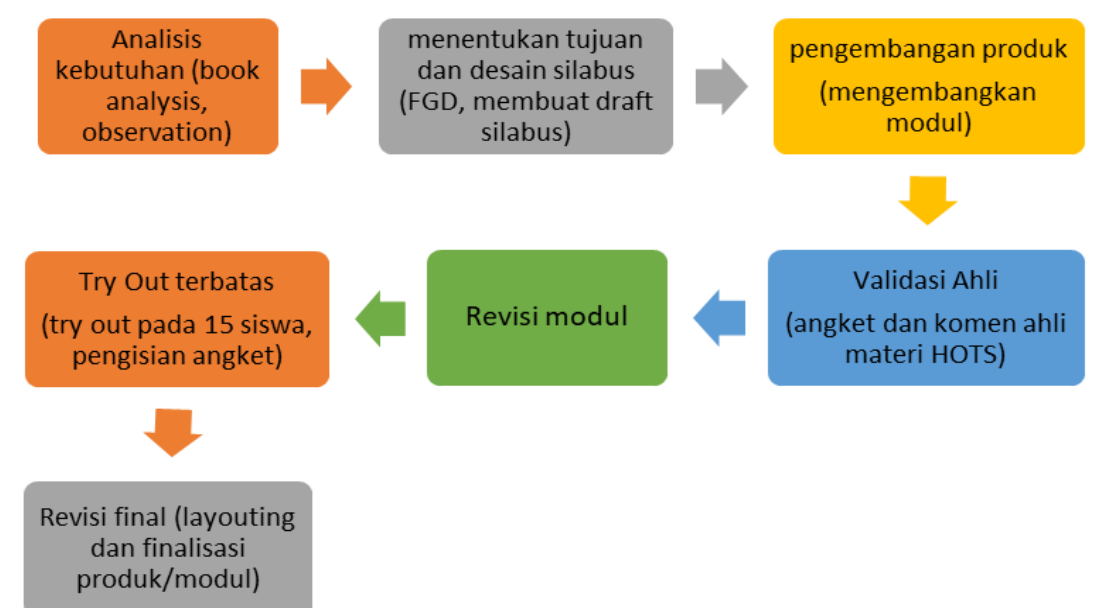

\section{Gambar 1. Alur penelitian pengembangan}

Penelitian ini dilaksanakan di MTs Al Falaah Pandak dengan populasi selurh siswa kelas VII MTs. Sample dalam penelitian ini adalah 15 siswa kelas 7 .

Untuk mengumpulkan data, penulis menggunakan angket untuk guru dan siswa, serta angket untuk ahli materi.

Untuk menganalisis data, peneliti menggunakan metode deskriptif kuantitatif yang mana data dari kusioner siswa akan dideskripisikan secara statistic dalam bentuk prosentase dan frekuensi. Sedangkan data dari ahli materi akan dideskripsikan secara statistic dengan menunjukkan rerata dan standar deviasi yang dikategorikan ke dalam 4 kategori, sangat baik, baik, cukup dan kurang. 


\section{PEMBAHASAN}

Modul pembelajaran Bahasa Inggris ini dikembangkan dengan mengaplikasikan langkah-langkah desain penelitian Borg and Gall. Langkah-langkah tersebut adalah dengan melakukan analisis kebutuhan, menetapkan tujuan, mendesain silabus, membuat draft modul, uji ahli materi, dan melakukan ujicoba serta diakhiri dengan revisi untuk menghasilkan produk yang sesuai dan layak untuk digunakan.

Analisis kebutuhan (need analysis) dilakukan dengan dua metode, angket kepada guru dan analisis buku ajar. Dari angket yang diberikan oleh 2 guru bahasa Inggris diketahui bahwa hanya ada 1 buku yang digunakan oleh guru dan siswa dalam pembelajaran, yaitu Lembar Kerja Siswa (LKS). LKS tersebut belum berbasis pada HOTs/ Higher Order Thinking Skills dan perlu dibuatkan modul yang berbasis HOTs. Dari angket tersebut juga ditemukan bahwa guru masih merasa sumber LKS tersebut kurang memadai dalam memfasilitasi pengembangan HOTs para siswa. Untuk latihan yang menghasilkan produk, LKS tersebut masih sangat kurang. Latihan-latihan yang ada dalam LKS tersebut masih banyak yang berorientasi pada LOT. Hal ini terbukti dari analisis buku yang dilakukan oleh peneliti dengan menganalisis isi buku bab 2 sampai 4 disesuaikan dengan $3 \mathrm{KD}$ yang dikembangkan. Adapun hasil dari analisis buku yang dilakukan dibahas dalam 3 aspek, tujuan, struktur buku dan aspek HOTs yang muncul dalam buku tersebut.

\section{Tujuan Pembelajaran}

Dari hasil analisis buku, sudah ada tujuan umum ditiap babnya, namun tidak dimunculkan tujuan yang secara spesifik. $\mathrm{KI}, \mathrm{KD}$, tema materi dan apersepsi muncul diawal tema. Namun, dalam apersepsi hanya berisi tentang pengertian dari tema besar dalam bab tersebut. Tujuan umum tidak mengacu pada KI dan KD dari bab tersebut. Contohnya dalam Bab kedua (Chapter2) tujuan hanya muncul di akhir apersepsi dengan kalimat 'With the various expressions that I describe, it is expected that you will be more varied in speaking English.' Jika dilihat Kompetensi Dasar dari bab ini yang secara ringkas menyatakan tujuan dari bab ini adalah siswa mampu mengidentifikasi fungsi sosial dan unsur kebahasaan teks interaksiterkait jati diri dan mampu menyusun teks interaksi transaksional sederhana maka bisa dinyatakan bahwa tujuan dari pembelajaran ini belum tersusun secara rinci.

\section{Struktur Buku}

Berdasarkan analisis yang dilakukan, struktur pengembangan bahan ajar yang digunakan dalam buku di madrasah ini menggunakan model pembelajaran yang menerapkan sintak Observing, Questioning, Associating, dan Commuicating. Namun dalam aplikasinya belum terlihat pada setiap babnya.

\section{Aspek muatan HOTs}

Menurut Anderson and Krathwool (2006) aspek HOTs dalam kegiatan pembelajaran adalah kegiatan mengaplikasikan, menganalisa, mengevaluasi, dan mencipta. Dalam buku ajar yang dipakai di MTs Al Falaah, kegiatan kegiatan yang mencakup aspek HOTs hanya sedikit, untuk kegiatan mencipta hanya ditemukan satu, didalam bab ke-3, namun tidak ada ruang untuk siswa menulis dilembar 
kerjanya. Kebanyakan aktifitas yang ada dalam buku ajar masih berada dalam lingkup aspek LOTs (Lower Order Thinking Skills).

Langkah yang dilakukan setelah analisis kebutuhan adalah dengan menetapkan tujuan pembelajaran dan merancang silabus dilakukan. Untuk tujuan modul akan dikembangakan sesuai dengan KD dari kurikulum 2013 yaitu KD 3.2, 4.2, $3.3,4.3,3.4$, dan 4.4 yang kegiatan pembelajarannya didasarkan pada pengembangan aspek HOTs.

Modul ini dikembangkan dengan menggunakan pendekatan saintifik yang mengimpelementasikan langkah-langkah pembelajaran discovery learning. Adapun langkahlangkah pembelajaran yang dimunculkan berdasarkan discovery learning tersebut adalah: Pemberian rangsangan (stimulation), Identifikasi masalah (problem statement), Pengumpulan Data (data collection), Pengolahan Data (Data Processing), Pembuktian (Verification), dan Penarikan Kesimpulan (generalization). Aktifitas - aktifitas yang muncul dalam tiap aspek akan disesuaikan dengan level kognisi dan keterampilan yang akan dikuasai oleh siswa, dengan memasukkan aspek HOTs di tiap temanya.
Setelah penyusunan silabus, maka pengembangan modul dimulai dengan mengembangkan modul dan pembuatan video pendukung materi dalam modul. Video digunakan sebagai supplemen materi dalam modul karena video dapat memberikan rangsangan sensorik pada peserta didik, dengan video peserta didik tidak hanya melihat tulisan dan gambar yang tercetak, namun juga mendengar dan membaca (Kholis, 2018). Selain menggunakan silabus sebagai dasar menyusun aktifitas dalam modul, materi tentang kebahasaan, kegiatan refleksi dan evaluasi juga disertakan dalam pengembangan modul. Unit 1 dalam modul ini bertema perkenalan diri dan diberi judul tema 'Halo. Let me introduce myself. Unit kedua bertema tentang waktu yang diberi judul 'What time is it?' dan unit terakhir dalam modul ini bertema tentang bendabenda yang ada disekitar kita dan diberi judu'Things around us.'

Setelah modul tersusun langkah selanjutnya adalah review modul atau validitas ahli materi. Adapun hasil dari review modul oleh ahli materi adalah sebagai berikut:

Tabel 1. Analisis Aspek Kelayakan Materi

\begin{tabular}{r|l|c|c|c}
\multicolumn{1}{c|}{ No } & \multicolumn{1}{c}{ Aspek } & Item & Rata-rata & Kategori \\
\hline 1 & $\begin{array}{l}\text { Kesesuaian dengan KI, KD, dan } \\
\text { tujuan pembelajaran }\end{array}$ & $1-5$ & 3,3 & Sangat baik \\
\hline 2 & Aspek kebahasaan & $6-9$ & 3,5 & Sangat baik \\
\hline 3 & Penerapan HOTs & $10-13$ & 3,2 & Baik \\
\hline
\end{tabular}

Beberapa catatan dan masukan ahli materi meliputi sisi kesesuaian diberikan dalam kaitannya dengan tujuan dan aktifitas, beberapa kelayakan modul yang telah disusun. kesalahan bahasa masih ditemukan Adapun catatan dan komentar dari dalam modul. 
Tabel 2. Analisis Aspek Lay-out dan Video Pendukung

\begin{tabular}{|c|c|c|c|c|}
\hline No & Aspek & Item & Rata-rata & Kategori \\
\hline 1 & $\begin{array}{l}\text { Tampilan modul (Kertas, ukuran dan } \\
\text { bentuk huruf, warna, dan kejelasan) }\end{array}$ & $14-17$ & 3,6 & Sangat baik \\
\hline 2 & Aspek visual (gambar dan tata letak) & $6,7,8,9$ & 3,25 & Baik \\
\hline 3 & Video pendukung & $10,11,12,13$ & 3,6 & Sangat baik \\
\hline
\end{tabular}

Selain mengisi angket, ahli melakukan revisi pada modul yang materi juga memberikan catatan telah disusun sebelum proses ujicoba. masukan dalam kaitannya dengan Adapun catatan komentar yang layout dan video pendukung. Dari membutukan perbaikan yang analisis ahli materi tersebut, peneliti diberikan oleh ahli materi adalah:

Tabel 3. Komentar Ahli Materi dan Revisinya

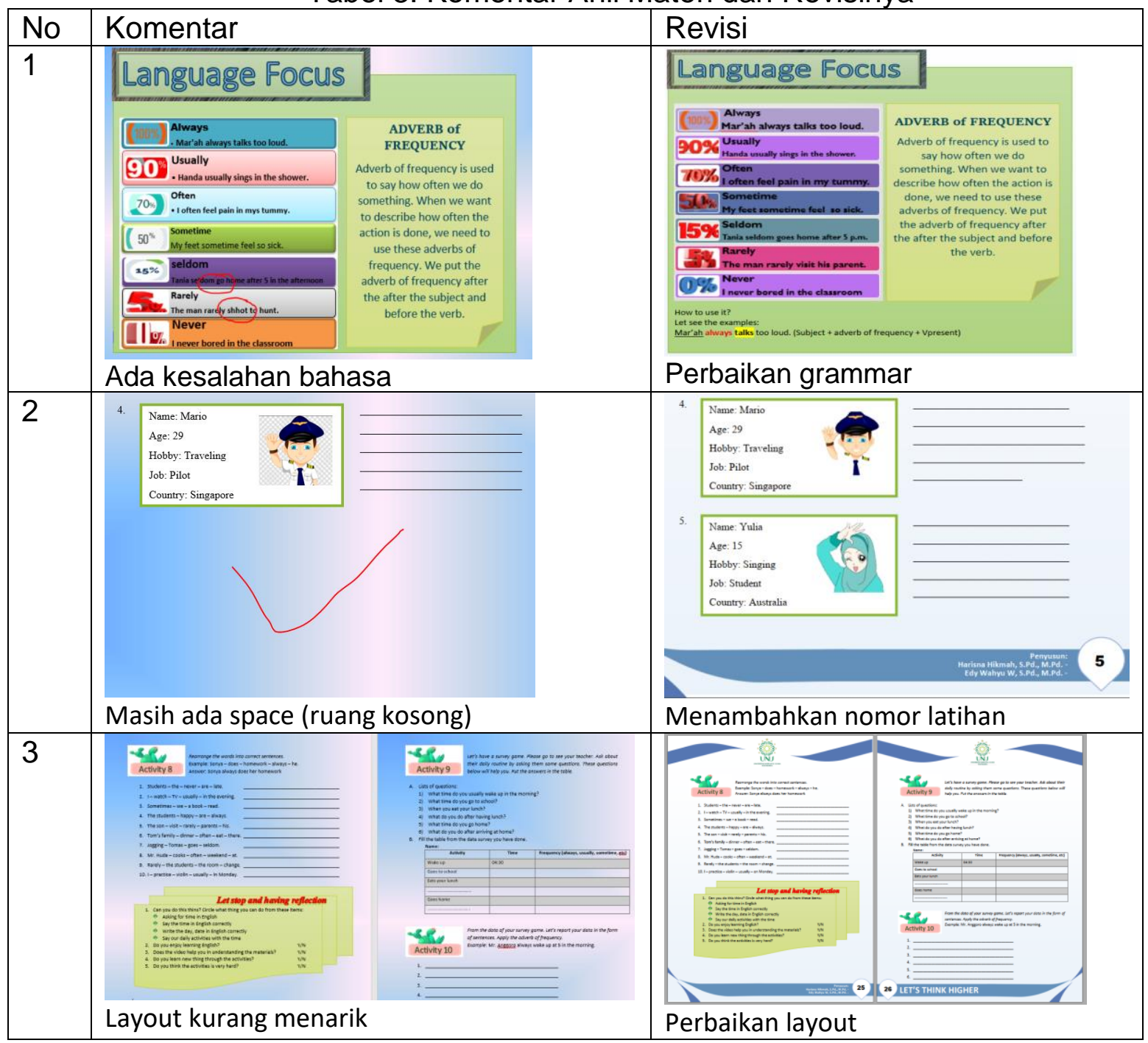




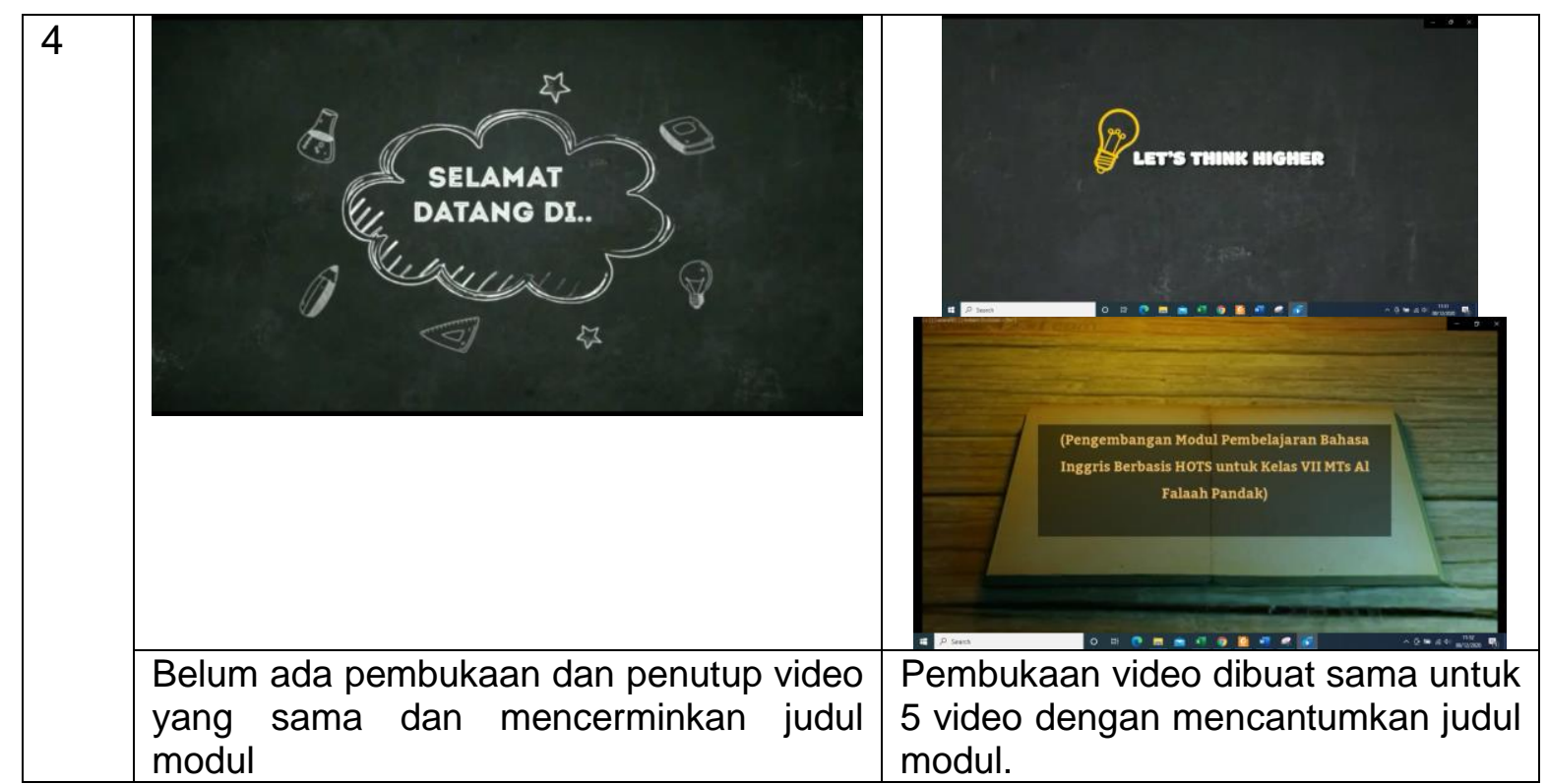

Setelah melakukan revisi modul 4. Uji coba modul ini dilaksanakan berdasarkan catatan dan komentar selama 4 kali pertemuan untuk melihat ahli materi, ujicoba dilakukan dengan kelayakan materi dan tampilan modul melibatkan 15 anak kelas VII. Angket yang telah disusun. Adapun hasil dari tersebut terdiri dari pertanyaan yang ujicoba dengan skala kecil ini adalah: dikembangkan dengan penilaian skala

\section{Tabel 4. Hasil Analisis Data Uji Coba}

\begin{tabular}{|c|c|c|c|}
\hline No & Aspek & Rata-rata & Kategori \\
\hline 1. & Tujuan Pembelajaran & 3,31 & Sangat Baik \\
\hline 2. & Susunan Modul & 3,23 & Baik \\
\hline 3. & Aktifitas HOTs dalam modul & 3,22 & Baik \\
\hline 4. & Bagian penjelasan materi dan refleksi & 3,19 & Baik \\
\hline 5. & Layout dan video penyerta & 3,20 & Baik \\
\hline
\end{tabular}
dapat diketahui bahawa aspek tujuan pembelajaran yang ada dalam modul tersebut mempunyai rerata 3,31 yang masuk ke dalam kategori sangat baik, ini berarti modul tersebut sesuai dengan kebutuhan siswa dalam belajar Bahasa Inggris. Untuk aspek susunan modul, nilai rerata yang didapatkan adalah 3,23 yang masuk dalam kategori baik. Hal ini bermakna siswa merasa nyaman dengan susunan modul. Untuk aspek aktifitas yang mendasarkan pada aspek HOTs mendapatkan nilai rata-rata 3,22 yang masuk dalam kategori baik. Hal ini

sesuai dengan tujuan penelitian ini, yaitu mengembangkan modul yang berbasis HOTs.

Sedangakan untuk aspek penjelasan materi dan refleksi yang ada dalam modul, nilai rata-rata yang didapatkan adalah 3,19 . Nilai ini masih masuk dalam kategori baik, sehingga bagian ini baik tetap dipertahankan dalam modul. Aspek terakhir dalam modul ini adalah aspek layout modul serta video penjelas yang dipakai dalam pembelajaran. Aspek ini mendapat nilai rata-rata 3,20 yang masuk kedalam kategori baik. Maka rerata dari semua aspek yang ada 
didalam modul bernilai 3,20 yang termasuk dalam kategori baik dan layak untuk digunakan dalam pembalajaran Bahasa Inggris di MTs Al Falaah Pandak.

Hasil penelitian pengembangan modul ini sesuai dengan penelitian yang dilakukan oleh Hamdan, dkk (2018) yang menyatakan bahwa HOTS Self-Instructional Manual terbukti efektif dalam meningkatkan prestasi penugasan siswa di level universitas. Selain itu, penelitian yang dilakukan oleh Sianturi, dkk (2020) juga menemukan bahwa pertanyaan atau instruksi kegiatan berbasis HOTS dapat meningkatkan kemampuan menulis siswa SMP.

Hasil akhir dari penelitian ini berbentuk modul pembelajaran Bahasa Inggris berbasis HOTS yang mengaplikasikan langkah-langkah pembelajaran discovery learning. Adapaun urutan aktifitas dalam modul tersebut bisa dilihat dalam diagram dibawah:

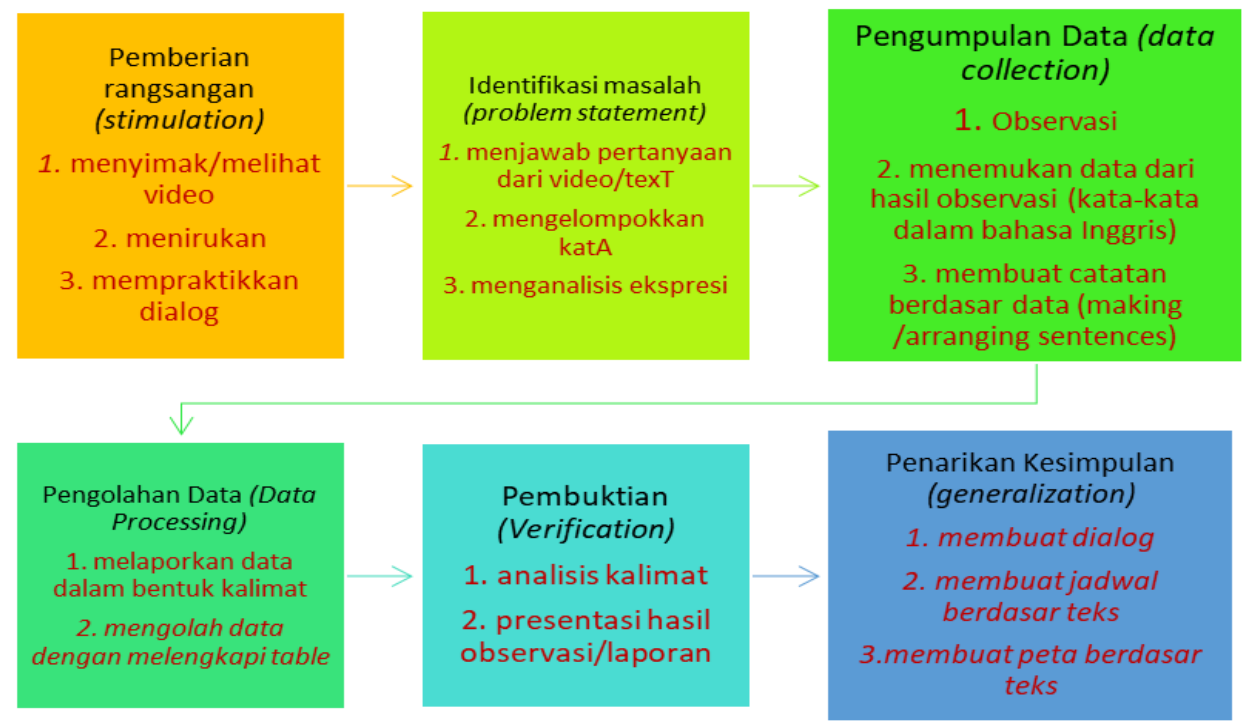

Gambar 2. Susunan Langkah Pembelajaran dalam Modul

Penelitian ini juga sejalan dengan penelitian yang dilakukan oleh Lestari (2019) yang menyatakan bahwa bahan ajar berbasis HOTS efektif digunakan dalam meningkatkan prestasi belajars siswa SMK.
Hipotesis yang terbukti adalah siswa yang pembelajarannya menggunakan bahan ajar berbasis HOTS lebih efektif daripada yang menggunakan buku teks.

\section{SIMPULAN}

Dari hasil pembahasan itu dapat disimpulkan bahwa pengembangan bahan ajar atau modul pembelajaran berbasis pada HOTs masih sangat diperlukan sampai pada saat ini. Dalam penelitian ini terungkap bahwa guru dan sekolah masih mengandalkan buku/bahan ajar dari luar. Terkait dengan hal tersebut, pengembangan modul Bahasa Inggris berbasis HOTs ini mendapatkan respon yang baik dari siswa dan juga dari guru serta dinilai layak digunakan dalam pembelajaran Bahasa Inggris di 
MTs Al Falaah Pandak berdasarkan pada hasil angket siswa dan juga hasli penilaian dari ahli materi. Namun demikian, kreatifitas guru dalam menggunakan berbagai sumber dan juga dalam mengambngkan materi sendiri yang didasarkan pada kebutuhan siswa, guru, stakeholder masih sangat dibutuhkan. Sudah selayaknya pula sekolah memberikan kesempatan bagi guru-guru Bahasa Inggris khususnya untuk meningkatkan kemampuannya dalam mengembangkan modul yang sesuai dengan visi misi dan karakter satuan Pendidikan.

Penelitian ini masih sangat terbatas pada pengembangan HOTs untuk pembelajaran Bahasa Inggris kelas rendah dan hanya pada beberapa kompetensi dasar yang diambil dari kurikulum 2013. Proses uji coba modul juga dilaksanakan secara online dan ofline dikarenakan kondisi pandemic Covid-19. Maka pengembangan modul berorientasi HOTs masih sangat terbuka lebar.

\section{DAFTAR PUSTAKA}

Anderson, L.W., \& Krathwohl (Eds.). (2001). A taxonomy for learning, teaching, and assessing: $A$ revision of Bloom's taxonomy of educational objectives. New York: Longman.

Depdiknas. (2014). Permendiknas Nomor 70 Tahun 2014. Kerangka Dasar dan Struktur Kurikulum Sekolah Menengah Kejuruan/Madrasah Aliyah Kejuruan.

Hamdan, N., dkk. (2018). An Effectiveness of High Order Thinking Skills (HOTS) SelfInstructional Manual for Students' Assignment Achievement. Journal of Technical Education and Training. VOL. 11 NO. 1 (2019) 063-072.

http://penerbit.uthm.edu.my/ojs/i ndex.php/jtet

Hutchinson, T. \& A. Waters. 1987. English for Specific Purposes. Cambridge:

Cambridge University Press

Kholis, A. (2018). The Effectiveness of Using Video And Pictures In Teaching Writing Hortatory Exposition Text. LingTera, 5 (2),
2018 ,

189-198.

http://journal.uny.ac.id/index.php/ litp

Lestari, R. (2019) Pengembangan Bahan Ajar Bahasa Inggris Berbasis Higher Order Thinking Skills (HOTS) Pada SMK Pelayaran di Kota Medan. Universitas Negeri Medan. http://digilib.unimed.ac.id/35984/ Retrieved on 8 December 2020

Margana dan Widyantoro A. (2017). Developing English Textbooks Oriented to Higher Order Thinking Skills for Students of Vocational High Schools in Yogyakarta. Journal of Language Teaching and Research, Vol. 8, No.1. Cited from https://eprints.uny.ac.id/36668/ on August 18, 2019

Renandya, W. (2013).Responding creatively to the new 2013 english language curriculum in Indonesia. A plenary paper delivered at the 10th JETA Conference, Sarjanawiyata Tamansiswa University Yogyakarta

Tomlinson, B. (2008). English language learning materials: a 
critical review. New

York:Continuum International Group.

Wells, B. (1987) Apprenticeship in Literacy. Dalam Interchange 18,1/2:109-123.

Zahroh, S. (2019). Integrating HigherOrder Thinking Skills (HOTS) to Increase Students' Productive
Skills.

https://semnas.untidar.ac.id/wpcontent/uploads/2019/07/SitiZahroh_Integrating-HigherOrder-Thinking-Skills-HOTS-toIncrease-Students-Productiveskills.pdf retrieved on 5 Decemeber 2020 